Снежана С. БАШЧАРЕВИЋ*

Универзитет у Косовској Митровици Учитељски факултет у Лепосавићу
Оригинални научни рад

Примљен: 08. 10. 2019.

Прихваћен: 12. 02. 2020.

\title{
СТВАРНОСНА ОСНОВА КИШОВЕ ЕНЦИКЛОПЕДИЈЕ МРТВИХ
}

\begin{abstract}
Данило Киш неговао је технику цитата и монтаже спајајући документарно и имагинарно. Говорио је о својим књигама настојећи да читаоцима предочи уметничке подстицаје, намере и образложи одређени уметнички поступак. Чинио је то на два начина: интервјуима и post scriptum-ом. Рад има за циљ да на примеру „Енциклопедије мртвих” аналитичко-синтетичком методом укаже на поетички принцип овог писца ослањајући се на експлицитне исказе. Извешћемо закључак да поетички принцип Данила Киша јесте стварање на основу истинитих догађаја, који се заснива на употреби цитата, докумената, књига, публикација; односно да „Енциклопедија мртвих” има стварносну основу.

Кључне речи: Д. Киш, „Енциклопедија мртвих”, цитат, документ, интервју, post scriptum, експлицитно, имплицитно.
\end{abstract}

Жанровске промене у књижевности двадесетог века доживеле су кулминацију и од тада се поетика и структура текста мењају веома брзо. Проза је постала подложна трансформацијама, чему је допринела отворена структура. У њеној форми долази до мешања различитих стилова, стварног са фантастичним, историјског са интимним. Она све више губи традиционалне кључеве и постаје врста комбинаторике прозе у писмима, сећањима, иницираних техником пронађеног рукописа и сучељавања историјског и естетичког времена, ослобођеног хронотопа у свевремености и свепросторности. Енциклопедијска, антиутопистичка, авангардна, савремена проза, све су то именовања која покривају само део интересовања писца двадесетог века. Бројни ерудитски облици есејистичке природе, мета и интертекстуалног односа, вишемедијске и међудисциплинарне провенијенције и нове цитатности подвлаче, иницирају и сигнализирају нови вид виртуелне стварности писца и нови вид фантастичности и фасцинантности. На делу је трајни бунтовни естетизам писаца који на матрицу традиције уписује нове кодове и идиоме. 
Транформације прозе односиле су се и на интеракцију текста с новим уметностима и медијима: филмом, телевизијом и цитатношћу.

Општа одлика модерне књижевности је да руши традиционалне жанровске поделе и да комбинује стилове, врсте и форме приповедања (Марино 1997: 58). Српски писци све више проширују распон типолошких могућности књижевне фантастике. Класични облик праћен фолклорном фантастиком јавио се код Слободана Џунића, Милисава Савића и Видосава Стевановића; гробљанске приче о утварама са вампирским мотивом - код Борисава Пекића, Филипа Давида, Митка Маџункова; психолошка фантастика са елементима чудесног - код Миодрага Павловића, Бранимира Шћепановића, Филипа Давида и Саше Хаџи Танчића; демонски натурализам - код Миодрага Булатовића; метафизичке скривалице, загонетке и магијски реализам - код Љубише Јоцића, Милорада Павића и Данила Киша; негативне утопије - код Ерика Коша и Добрице Ћосића и гротеска - код Радомира Смиљанића. У новијој српској прози развили су се и неки самородни постмодернистички видови књижевне фантастике, као што су фантастични реализам, критичка фантастика и критичка иронија - код Борислава Пекића, Светлане ВелмарЈанковић; односно тежња ка деконструкцији и скептичком разлагању како миметичких тако и немиметичких приповедачких форми - код Давида Албахарија, Светислава Басаре, Миленка Пајића, Немање Митровића. Толико богатство могућности и такво обиље фантастичних жанрова иду у прилог тврдњи да у духовном простору савремене књижевности фантастика није, нити може бити, само пука игра.

Познато је да за једно књижевно дело није пресудна тема којом се његов аутор бави, већ начин на који је та тема уметнички обликована. Кишова техника приповедања заснована је на стилизацији приче путем документа и фикције, што га је упутило на успостављање новомитских ситуација, нову фантастику. Документа сада бивају део историјске и биографске грађе. Он наставља традицију „отежале форме” руских формалиста, чиме меша објективну и естетичку стварност. За стваралаштво Иве Андрића у једном од разговора рекао је: „По том стваралачком односу према збиљи, Андрић спада, дакле, у ред оних писаца који су у први план своје поетике ставили истинитост фиктивне творевине, и тиме приповедачкој уметности дали већу одговорност, а европској прози отворили путеве ка новим могућностима и новим проседеима" (Киш 1995a: 13).

Пекић, Киш и Павић припадају генерацији српских прозаиста који нову осећајност настоје да изразе на модеран начин. У овом контексту појам „модерно” треба разумети као отклон од конвенционалне, типизиране наративности, независно од времена настанка књижевног дела (Лукић 1987: 65). Али, треба имати у виду да је њихово разумевање модерности праћено уверењем да није сасвим могуће одбацити старе форме, већ их је, премоделовањем или рекомбинацијом, могуће ставити у функцију новог, ововременог сензибилитета. Реч је, наиме, о модерном наслеђивању класичних образаца књижевне речи.

Данило Киш неговао је технику цитата и монтаже спајајући документарно и имагинарно. Цитатност је врста интертекстуалности заснована на 
уметничком поступку у коме аутор у властити текст уноси туђи текст. Њоме се модификује семантика властитог текста на рачун веза с текстом - изворником (Речник књижевних термина 2001: 107-108). Цитат се наводи као потврда или илустрација за неки догађај и он постаје саставни део унутрашње структуре књижевног дела и начин повезивања са културном традицијом, а монтажа у књижевности представља састављање наизглед разнородних мисли и исказа који својим међусобним односима уметнички делују и служе одређеној уметничкој сврси.

У Кишовој прози има цитата из литерарних и нелитерарних извора, писама и докумената. Та техника, позната у страним књижевностима (Борхес), није наишла на разумевање књижевне критике када се појавила књига „Гробница за Бориса Давидовича". Критика је била непринципијелна, настао је сукоб два табора: оних који су теоријским аргументима бранили Кишов књижевни поступак, и оних који су оптуживали писца за плагијат. Као одговор на ове нападе, Киш је објавио полемичку књигу „Час анатомије” у којој је написао: „Нема сумње, приповетка, тачније речено приповедачка уметност, дели се на ону од Борхеса и на ону после Борхеса. И ту не мислим на проширење поља реалности (у правцу фантастике), него у првом реду, на саму технику приповедања; мопасановско-чеховљевско-о'хенријевско приповедање, које је тежило детаљу и које је стварало своје поље митологема индукцијом, замењено је код Борхеса једним чаробњачким и револуционарним потхватом, дедукцијом, што је само друго име за својеврсни приповедачки симболизам, чије су пак косеквенце, на теоријском и практичном плану, не мање од оних које је извршио тај исти симболизам у поезији са појавом Бодлера. Уз то, поменути индуктивни метод, доживевши своје врхунце у приповедачкој уметности поменуте тројице великана тзв. реалистичке приче, чини ми се да је искористио сва своја средства и да данас, по принципу смењивања сензибилитета и консеквентне књижевне реакције, делује најчешће као анахронизам" (Киш 1995б: 56-57).

Кишова проза је ерудитна и интелектуалистичка: поред бројних цитата (видљивих и скривених) и докумената, она садржи обиље литерарних алузија и асоцијација, које проширују границе културног и књижевног контекста. Независно од сваке књижевне школе и њене могуће дидактике самостално је испитивао нову технику приповедања, стилизацију и симболизацију приче. То га је, по природи ствари, упутило на већ поменуту интертекстуалност, цитатност, метатекстуалност, циклизацију културе, даље проблематизовање и преплитање жанрова у структури романа, текст у функцији палимпсеста и специфичности у времену и цивилизацији, демитологизацију и успостављање новомитских ситуација, пројекат библиотеке у књизи, симболе лавиринта, клепсидре, огледала и музеја. У Кишовом случају сложеност се указује као савршена симетрија, а нова фантастика као ерудиција литературе будућности. Он је сматрао да читалац више не верује у измишљотине, тако да постојећи и измишљени документ имају функцију илузионисања реалности и објективизације дедукције. У „Часу анатомије” написао је: „Модерна форма фантастике јесте ерудиција, речено је поводом Борхеса, ако се не варам. Ова кратка констатација садржи, међутим, читаву једну поетику модерне литера- 
туре и, рекао бих, та је наведена формулација заправо темељ целокупне модерне литературе. Шта се том формулом жели рећи? Да је време измишљања прошло, да читалац више не верује у измишљотине, јер му је модерно време, у констелацији 'светског села' које умножава бизарна факта стварности, показало да она фамозна фраза Достојевског да 'ништа није фантастичније од стварности', није само спретна доскочица једног књижевника, већ се та фантастика стварности приказала модерном човеку као фантастична стварност" (Киш 1995б: 68).

Киш је настојао да причу сведе на чињенице, а фактографска природа правог и лажног документа за то је идеална. Документ као цитат један је од облика онеобичавања и „отежале форме” руских формалиста, чија је начела Киш ценио. У „Часу анатомије” експлицитно је изнео став: „Приморан сам да се позовем на Шкловског (и да се не би помислило да сматрам да се нове форме јављају као идеолошке косеквенце или да желим да дезавуишем 'старог доброг Чехова'): 'Уметничко дело се схвата на плану форме посредством асоцијација са другим делима уметности. Форма уметничког дела одређује се односом према другим формама које су постојале пре ње... Не само пародија, већ упоште свако уметничко дело ствара се као паралела и противтежа некаквом обрасцу. Нова форма се јавља не ради тога да изрази нову садржину, него да замени стару форму, која је већ изгубила своја уметничка својства" (Киш 1995б: 57).

У радовима руских формалиста заступљено је кретање ка унутрашњем приступу књижевном делу и иманентном проучавању књижевности. Формалисте занимају питања: како је књижевно дело начињено, од чега је начињено, какав је распоред грађе, каква је организација дела, место и улога структурних елемената, значење појединих елемената структуре, естетско деловање материјала из кога је дело обликовано (Милосављевић 2000: 412). У средишту испитивања формалиста су форма, материјал (грађа) и поступак. Суштина књижевног дела није у садржини, него у поступку. Он изванестетску грађу, придајући јој форму, претвара у уметничко дело. Уметнички поступак делује као изненађење (поступак онеобичавања) или као отежавање разумевања (поступак отежане форме). У првом случају реч је о необичном виђењу ствари. У другом случају отежано је разумевање форме што захтева интелектуални напор који има благотворно дејство на личност читаоца, јер га ангажује и не оставља га пасивним примаоцем.

Књижевно дело као предмет проучавања формалисти узимају као самосталан и аутономан феномен. С обзиром на то, књижевност има сопствену аутономну логику којој је подређено све што чини књижевни организам. Све ванестетско што улази као компонента књижевног дела саображава се законима књижевног дела, губи своју првобитну особеност примајући нову, уметничку функцију. Формалисти примењују интензиван метод проучавања: у средишту анализе је књижевно дело, тежиште је на естетским особеностима, истражује се уметничка функција језика. Интересује их поступак обликовања књижевног дела, пажљиво га изучавају и описују уводећи притом нове термине као најпримереније инструменте за даља истраживања. 
Киш је примењивао технику текстуалне транспозиције, при чему се цели делови или низови фрагмената, често у њиховом непромењеном стању, преузимају из других текстова и слободно интегришу у дело. За причу „Симон Чудотворац”, написао је: „То је варијација на тему једне од гностичких легенди" (Киш 1997: 155). Од импресоналне до личне прозе коју је писао кретала се дилема како одредити причу и преобразити је у текст, јер није важно рећи извесне ствари, важно је рећи их на известан начин.

Тако прича постаје аморфна форма отвореног текста. Наратор постаје транслатор, коментатор и комбинатор. „Фламански мотиви у причи надахнути су атмосфером која зари из слика Тербоха, Рубенса, Рембранта, и њиховим интерпретацијама, као и сећањем на један хамбуршки излет из године 1972.” - написао је, везано за причу „Посмртне почасти” (Киш 1997: 156). Све више се мешају објективна и естетичка стварност. Нова аутопоетичка самосвест условила је нови приступ прози, појаву старог или изгубљеног рукописа као синкретичног конститутивног елемента приче. Кружење елемената у документима код Данила Киша показује способност фикционализације и оностраности путем најаутентичнијих доказа. У post scriptum-у за причу „Енциклопедија мртвих” објаснио је: „Особа која је сањала овај сан, и којој је прича посвећена, једног је дана открила, не без чуђења блиског дрхтају, да су њени најинтимнији кошмари већ материјализовани у тврдом камену, као какав чудовишан споменик” (Киш 1997: 156). Док је код Борхеса документ сасвим апстрактан, код Киша има одређену заснованост у стварном животу. На ту тему у „Часу анатомије” написао је следеће: „Уместо произвољног измишљања, држати се докумената и историјских чињеница, пре свега на нивоу фабуле" (Киш 1995б: 70). Факат је оно што ову прозу држи за тле литературе да се не претвори у чисту фикцију. Он је средство остваривања поетичких ефеката и значи техничку могућност иновације прозе. Између факта и фикције налази се мотив смрти. Смрт је вечита енигма, тајна равна мистерији рађања, али интензивнија од ње због ужаса нестајања. Смрт је неотклоњиви крај који све равна. Коначна, драстична чињеница живота, прихватање неприхватљивог, последња спознаја о којој се не може сведочити, јер немате повратно искуство у живот. Она је стога естетички функционална у делу Данила Киша као поетички део тријаде коју чини с фактом и фикцијом. На ту тему, везано за причу „Легенда о спавачима” написао је: „Грегоар де Тур (умро 594) сматра, као и Саруг, да је ово буђење један од доказа ускрснућа мртвих" (Киш 1997: 158).

Писац сведочи да је документ карика која држи фантазију везану за стварност. Артефакт Данила Киша мора деловати као истинитији од било ког документа у животу да би пружио могућност занимљивих техничких иновација модерне приповедачке уметности. Колико је у Кишовом делу видљива граница између факта и фикције, толико је невидљива између фикције и смрти. У „Енциклопедији мртвих” документ добија функцију мотивације, фикција службу виртуелности, а смрт функцију симболизације. Тим поводом написао је: „Ја сам био приморан, изабирајући теме за свој циклус прича, да се послужим фабулама у чију се аутентичност не би смело посумњати" 
(Киш 1995б: 71). Сматрао је да литература апсолутно не може да избегне смрт. Тражећи одговоре на питања о бесмртности душе, није правио само литерарне коментаре о смрти који без сумње представљају жанр у жанру, већ је поставио синдром смрти као носач читавог дела. Кишова литература је живела смрт и писала сопствену смрт. Тим поводом наводимо његов експлицитни исказ: „Не пишем као професионалац, него као 'песник', што ће рећи бавим се искључиво својим сопственим опсесивним темама, у некој врсти песничког заноса, и бирам само оне теме и проблеме који ме опседају интимно, што ће рећи интелектуално и морално или у некој лирској симбиози интелектуално-моралног” (Киш 1995б: 71-72).

Појава књиге „Енциклопедија мртвих” изазвала је лавину реаговања, оштре расправе у новинама и на трибинама, јер је доносила нешто што је било ново и непознато у нашој књижевности како на формалном тако и на семантичком плану. Као таква, она ће дати смер новом доживљају света, указати на поетику која почиње да покреће чуђење, питања и дилеме о смислености писања. Све се то дешавало због тога што је Кишово дело грађено на сликама опорим и шокантним, било атак на укус целог једног времена. У књизи „Енциклопедија мртвих” он је најодлучнији поборник модерног, изазован у односу на владајући укус и стил. Својим стваралаштвом тражио је могућности излаза пред разарањем света. Судбина људског друштва дата је у напетости између два супротна пола, изгубљене ведрине и спокојства и растројства и дехуманизације савременог света.

У „Енциклопедији мртвих” тема смрти присутна је у свим новелама, a све су писане на различите начине. Смрт представља метафору за крах цивилизације, а писање одупирање злу и дехуманизацији. Киш је у једном од својих телевизијских интервјуа изјавио: „Ја сам човек са песимистичним погледом на свет, а то је последица животног искуства или наслеђа” (Кривокапић 1982). То је књига самосталних приповедака окупљених у целину, односно, тематска циклизација са историјским и цивилизацијским темама које задиру у људску егзистенцију. Свака приповетка има своје јунаке који се не појављују у осталим причама, као и различито просторно и временско одређење. Једина везивна нит је смрт као неминован судбински избор. При одређивању тематске суштине сваке приче, потребно је обратити пажњу на податак на крају под називом post scriptum, који почиње овом реченицом: „Све приче у овој књизи у већој или мањој мери у знаку су једне теме коју бих назвао метафизичком; од спева о Гилгамешу, питање смрти једна је од опсесивних тема литературе" (Киш 997: 155). То су белешке са ближим одредбама, чији текст материјализује чињенице.

Просторни и временски планови прича су неподударни. То се само површном читаоцу може учинити као врста формалне издељености књиге на онолико прича колико је наслова у садржају, јер кад се на крају, пошто се прочита цела књига, покуша дати суд, запажа се низ унутрашњих кохезионих, заједничких својстава. Ширина просторног плана је фактор кохезије. Ни ширина временског плана, а он обухвата оба миленијума хришћанске цивилизације, није фактор дезинтеграције и парцијализације, већ уметничке 
кохезије. Али оно што чини специфичност прозе „Енциклопедије мртвих” је тема о човековом супротстављању једноумљу и насиљу над човеком.

Кишова визија света је трагична. Његове личности не напушта ни за тренутак осећање бачености и изгубљености. Оне се сукобљавају са средином, пате од неразумевања, доживљавају слом, живе у кошмарном свету наврелих успомена, подсвесних жеља, немоћне да се ослободе опсесивних слика. Одсечене су од узрока и циља, бачене у амбис садашњости без могућности да сагледају прошлост и наслуте будућност. У овој књизи говори се о патњи, бризи и стрепњи бића стављеног у њему неразумљиве односе и везе лишене сваког смисла. „Енциклопедија мртвих” нуди безброј примера биолошког, социјалног и метафизичког зла. Индивидуална настојања свих својих јунака који трагично завршавају, посебно у причама „Славно је за отаџбину умрети”, „Посмртне почасти”, „Црвене марке са ликом Лењина”, зато што историја и природа друштва у њима потенцирају смрт - Данило Киш симболички функционализује дајући им смисао означавања свеопштег људског, па према томе, и цивилизацијског пропадања. Једна порука нам остаје у свести после сваке прочитане Кишове приче: сваки однос човека према животу и свету дословно је производ њега самог и он мора да поднесе притисак постојања, савлада у себи очајање проузроковано сазнањем своје несрећне судбине.

На крају, можемо извести закључак да је Данило Киш писац који је изградио особен и препознатљив књижевни свет. Његово дело није лако разумети, јер га је довео у велику зависност од образованог читаоца и не слутећи да је тиме изрекао најадекватнији суд о себи и свом стваралаштву. Афирмисао је став да, када је у питању књижевност, није важан број, мноштво читалаца, већ духовно сродство читаоца с писцем. Кишова проза тражи нарочитог читаоца и тек са таквим читаоцем и у таквом читаоцу текст реализује свој естетички потенцијал, поетичку вредност и значењску пуноћу. Он је својим делима револуционарних домета одбацио све што је било индиферентно спрам егзистенцијалних удеса и страхова. Устао је против мистификације живота и свега онога што је књижевно непродуктивно. Борио се за нови квалитет писања, који подразумева што интензивније, комплексније и луцидније сагледавање проблема, тј. за интелектуализацију књижевног простора. Његова проза је превасходно интелектуална и мисаона, модерна и аутентична, снажна, смела у садржини и изразу и снажну, зрелу мисао ставља поред бесмисла, који је прецизно темпиран на један утисак и једну асоцијацију. Киш као писац новог сензибилитета, не прихвата стање канонизоване свести, једнообразну, упрошћену књижевну визију друштвене стварности која, судећи по присутним темама, тежи неутралном прилазу и идеализовању новостворене датости, у којој писац не иде толико за унутрашњим импулсима колико за диктатом споља. Дубоко свестан да књижевност живи од кретања, промена и идења напред, а видећи у постојећој само стагнацију, наступао је са жељом индивидуалисте да мења поетички простор. Кишово дело тражи стално ишчитавање и реинтерпретацију текстова на различитим нивоима. Управо ова тежња за реинтерпретацијом јесте жудња за сталним ревидирањем и пропитивањем дискурса. Његова реинтерпретација и посматрање текста кроз спектар плу- 
рала омогућила је разоткривање историје (стварности). Текст Данила Киша наводи читаоца на посматрање стварности у сталном покрету и на ту тему у једном телевизијском интевјуу изјавио је: „Измишљање је опасна ствар. Мене прожима стварност доживљаја и идеја. Писац је обавезан да проговори о стварности" (Кривокапић 1982). Целокупно стваралаштво овог писца је ерудитно и интелектуалистичко. Зато уме да буде загонетно и херметично. Све то чини да читаоци различито примају његове поруке. Концентрацијом својих убеђења о књижевности којих у експлицитној форми има више него било који српски писац, дао је велики замах поетичком убрзању и развоју српске прозе од шездесетих до деведесетих година, а иманентно је показао како то функционише у тексту. Играјући се формом, омогућио је ново активирање наше књижевности и својом светском славом омогућио је интерес за остале значајне писце, а „Енциклопедију мртвих” учинио је сигналним делом будућих еволуција у литератури. Синтагма која би могла објаснити сву сложеност Кишовог дела јесте „фактографисана фикционалност и фикционализована фактографија”. Његови есеји, полемике и интервјуи односе се на поетичке теме, а приповедање је проткано поетичким промишљањем. Предмет поетичког дискурса Данила Киша у прозној структури нису само општа поетичка питања стварања и стваралаштва, него су то и промишљања о неком свом књижевном делу. У „Часу анатомије” је написао: „Говорити о својим књигама књижевнотеоријски није више никакав хир, него нужност" (Киш 1995б: 9). Он је писац заокруженог поетичког система, који је разбио фаму о постојању искључиво критичарског мишљења на суд о неком књижевном делу и упустио се, како имплицитно, тако и експлицитно, у тумачење онога што је сам написао. Већ у самом процесу стварања, постао је истовремено и свој тумач и критичар. Потребним је сматрао интензивније и комплексније сагледавање проблема који се стално отварају, дају нове подстицаје у стваралаштву, нуде нову и друкчију акустику. Одбијао је упрошћеност која може да значи укидање стваралачког субјекта. Прихватао је само привременост наших знања и живео у уверењу да се књижевним делањем далеко стиже. Радио је на сталном мењању формуле човека, која се налази у свакој речи и гесту, дакле, у заједничкој моћи да је поправљамо и оплемењујемо.

\section{ЛИТЕРАТУРА}

Величковић 1998: С. Величковић, Документ и прича, Ниш: Градина.

Делић 1995: Ј. Делић, Кюижевни погледи Данила Киша: ка поетищи Кишове прозе, Београд: Просвета.

Делић 1997: Ј. Делић, Кроз прозу Данила Киша: ка поетици Кишове прозе II, Београд: БИГЗ.

Деретић 2004: Ј. Деретић, Историја српске књижевности, Београд: Просвета. Егерић 1971: М. Егерић, људи, књиге, датуми, Нови Сад: Матица српска. Зорић 1973: П. Зорић, Данило Киш или ходочашће прошлости, Београд: Нолит. 
Игњатовић 2012: С. Игњатовић, Проза промене. Српска проза 1950-1979, Београд: Службени гласник.

Јеремић 1976: Љ. Јеремић, Проза новог стила, Београд: Просвета.

Јеремић 1993: Љ. Јеремић, Глас из времена, Београд: БИГЗ.

Киш 1994: Д. Киш, Енщиклопедија мртвих , Београд: БИГЗ.

Киш 1995а: Д. Киш, Живот, литература, Београд: БИГЗ.

Киш 1995b: Д. Киш, Час анатомије, Београд: БИГЗ.

Киш 1997: Д. Киш, Ениклопедија мртвих, Београд: Књига-комерц.

Кривокапић Боро. Телескопија: Данило Киш. 1982. < https://www.youtube. com/channel/uce6lp5fa2pk-gpsbmloyp2g > 12. 07. 2019.

Лукић 1987: С. Лукић, Модерна интелектуална проза, Београд: Ново дело.

Марино 1997: А. Марино, Модерно, модернизам, модерност, Београд: Народна књига.

Милосављевић 2000: П. Милосављевић, Методологија проучавања књижевности, Београд: Требник.

Павловић 2002: М. Павловић, Поетика модерног, Нова Пазова: Бонард.

Палавестра 1972: П. Палавестра, Послератна српска књижевност (19451970), Београд: Просвета.

Пантић 1998: М. Пантић, Киш, Нови Сад/Београд: Светови/Књига-комерц.

Пелеш 1966: Г. Пелеш, Поетика сувременог југославенског романа (19451961), Загреб: Напријед.

Пијановић 1992: П. Пијановић, Проза Данила Киша, Приштина/Горњи Милановац/Подгорица: Јединство/Дечје новине/Октоих.

Речник књижевних термина 2001, Бања Лука: Романов.

Солар 1971: М. Солар, Питања поетике, Загреб: Школска књига.

Сребро 1985: М. Сребро, Роман као поступак у савременој српској књижевности, Нови Сад: Матица српска.

Срећковић 1977: М. Срећковић, Критички профили, Београд: Слово љубве.

Стојадиновић 1987: Д. Стојадиновић, Моћ говора савременог романа, Београд: Ново дело.

Тодоров 1986: Ц. Тодоров, Поетика, Београд: Филип Вишњић.

Џаџић 1973: П. Џаџић, Критике и огледи, Београд: СКЗ.

Шкловски 1969: В. Шкловски, Ускрснуће ријечи, Стварност: Загреб.

Snežana S. Baščarević

THE REAL BASIS FOR THE KIŠ „ENCYCLOPEDIA OF THE DEAD”

(Summary)

Danilo Kiš nurtured the technique of quotation and editing by connecting documentary and imaginary. He talked about his books in an effort to present readers with artistic incentives, intentions, and explained a certain artistic process. He did this in two ways: interviews and post scriptum. The 
paper aims to point out, on the example of the "Encyclopedia of the dead" by the analytical-synthetic method, the poetic principle of this writer, relying on explicit statements. We will conclude that the poetic principle of Danilo Kiš is the creation on the basis of true events, which is based on the use of quotations, documents, books, publications; that the "Encyclopedia of the dead" has a real basis. 